\title{
TOXICITY TEST OF Gracilaria sp. AGAINST Aspergillus niger van Tieghem AND THE PHYTOCHEMICAL ANALYSIS
}

\author{
Nevy Widya Pangestika, I Gede Putu Wirawan*, and I Ketut Suada \\ Faculty of Agriculture, Udayana University \\ Jl. PB. Sudirman, Denpasar, Bali 80232, Indonesia \\ *Corresponding author: igpwirawan@unud.ac.id
}

\begin{abstract}
The purpose of this study was to know the effectiveness of Gracilaria sp. ethanol extract to inhibit the growth of Aspergillus niger. The results showed that the ethanol extract of Gracilaria sp. was not effective to inhibit the growth of $A$. niger. The minimum inhibitory concentration test (MIC) was carried out using extracts with $0.1 \%, 0.2 \%, 0.3 \%, 0.4 \%, 0.5 \%$, $0.6 \%, 0.7 \%, 0.8 \%, 0.9 \%, 1 \%, 2 \%$ and $0 \%$ percentage. The MIC results showed that the minimum extract inhibiting A. niger was $0.8 \%$. The results of the antifungal activity test showed that the ethanol extract of Gracilaria sp. was fungistatic against A. niger. On the third day incubation, the $4 \%$ extract inhibited the growth of fungi with an average diameter of 5 $\mathrm{mm}$. The fungal colony test was carried out using extract with $0.5 \%, 1 \%, 2 \%, 4 \%$ and $0 \%$ concentration, and the results showed that extract with $4 \%$ concentration can inhibit fungi colony growth by $69 \%$. Phytochemical analysis was conducted using the UV-Vis Spectrophotometry, and the results showed that the ethanol extract of Gracilaria sp. contained $366.33 \mathrm{mg} / 100 \mathrm{~g} / \mathrm{GAE}$ phenol, $2041.47 \mathrm{mg} / 100 \mathrm{~g}$ flavonoids, and $3041.60 \mathrm{mg} / 100 \mathrm{~g} / \mathrm{TAE}$ tannins. Tannins are suspected to be the most dominant fungistatic compound with the largest amount.
\end{abstract}

Keywords: antifungal, seaweed., Aspergillus, UV-Vis.

\section{INTRODUCTION}

Aspergillus niger is a fungi that is often used in the food industry as it has hydrolytic and oxidative enzymes that are useful for breaking down plant lignocellulose. A. niger is one of the fungi that has been labeled with GRAS (generally recognized as safe) by the USDA (United States Department of Agriculture). But A. niger has been found to be an opportunistic reason for infection if inhaled by humans and cause aspergillosis, and this fungi is also associated with several important plant diseases. This fungi causes spoilage in some fruits, vegetables and other food products, resulting in huge economic loss. Plant diseases caused by A. niger include black rot of onions, crown rot of peanuts, tuber rot of yam, stem rot of dracaena, black mold rot of cherry, kernel rot of maize, fruit rot of grapes, fruit rot of banana, rot of tomatoes, and mango rotting. A. Niger can be found in soil, 
water, air, and decaying plant material (Gautam et al., 2011).

A. niger is generally known as a post-harvest fungi that grows well in the tropical climate. This fungi causes mycotoxin contamination which causes discoloration, loss of quality, and decreased commercial value of agricultural products. A. niger is also reported to contain ochratoxin A, fumonisin B2, and aflatoxin (AlAbdallah, 2009).

Fungi growth can be inhibited by using a fungicide. In general, the fungicide used by farmers is a chemical fungicide. The use of chemicals continuously has a negative impact on the environment so there is a need for substitution into more natural materials.

Nowadays, marine organisms such as macroalgae are one of the natural resources that can be explored as they contain broad-spectrum antifungal activity (Harman et al., 2004). Besides, macroalgae are also known to stimulate the growth of vegetables, fruits, and other plant parts with their metabolite content. The compound was extracted from different macroalgae families, such as green, brown, and red algae which are estimated to have 40,000 compounds (Raven et al., 1992).

Gracilaria sp. is one of seaweeds or macroalgae widespread in Bali which has been consumed for generations as vegetables. Based on previous research by Suada (2012), Gracilaria acuata has the ability to inhibit the growth of Fusarium oxysporum f.sp vanillae.

As an effort to explore its benefits as an antifungal agent, it is important to know the content of secondary metabolites of Gracilaria sp. The method used to determine the secondary metabolite content of plants is phytochemical analysis. The phytochemical analysis is a branch of pharmacognition that studies plant chemical analysis methods. Plant chemistry has now developed into a branch of science itself. This branch of science lies between the organic chemistry of natural materials and plant biochemistry which are interrelated between the two that studies the diversity of organic compounds contained in plants, chemical structures, biosynthesis, changes in metabolism, scientific distribution, and biological functions (Harborne, 1984).

This study is conducted using Spectrophotometry UV-Vis method. The advantage of using this spectrophotometric method is very simple to determine the number of substances that are very small. Spectrophotometry implies the measurement of the distance of light 
energy by a chemical system as a function of the wavelength of radiation, as well as the measurement of solitude absorption at a certain wavelength (Hasibuan, 2015).

\section{MATERIALS AND METHODS}

\section{Macroalgae material and preparation of the extract}

Fresh Gracilaria sp. was collected from Serangan Beach, Denpasar. Then wash the sample to clean the impurities with running water, then chopped to reduce the size. Then, dry the cleaned sample in the oven for 3-7 days with a temperature of $40^{\circ} \mathrm{C}$ until obtaining the constant weight. Extraction of the algae is carried out using maceration as follows: the finely powdered algae material $(500 \mathrm{~g})$ is macerated using $96 \%$ ethanol (2 L) at room temperature for three days with regular shaking. After the filtration, the organic solvent was evaporated under vacuum with the temperature of $50^{\circ} \mathrm{C}$ to obtain dry ethanol extract. The crude extract then stored at the temperature of $20^{\circ} \mathrm{C}$

\section{Media Preparation}

Media preparation is conducted by dissolving $3.9 \mathrm{~g}$ of PDA powder and $100 \mathrm{mg}$ of chloramphenicol in $100 \mathrm{ml}$ distilled water. Homogenize the solution using a magnetic stirrer, then autoclave at $121^{\circ} \mathrm{C}$ for 15 minutes. Pour $20 \mathrm{ml}$ PDA media into a sterile petri dish.

\section{Minimum Inhibitory Concentration} Test

A total of $500 \mu \mathrm{l}$ of fungi suspension was mixed with $20 \mathrm{ml}$ of a thin PDA (medium temperature around $42-45^{\circ} \mathrm{C}$ ) and shake horizontally until evenly mixed in a petri dish. After the PDA is freezing, make three diffusion wells using cork borer, then fill each diffusion well with extract of the concentration: $0.0 ; 0.1 ; 0.2 ; 0.3 ; 0.4 ; 0.5$; $0.6 ; 0.7 ; 0.8 ; 0.9$ and $1 \%$ as much as $20 \mu \mathrm{l}$ using a micropipette (Dewi et al., 2019). Inhibition Zone Test

A total of $0.5 \mathrm{ml}$ of fungi spore suspension of the conidia with the concentration of $2 \times 10^{5}$ conidia/ml was put into a petri dish, then poured with 20 ml PDA which was still liquid. The culture is shaken until the conidia are evenly mixed into all media. After the media is freezing, make the diffusion well with cork borer $\varnothing 5 \mathrm{~mm}$, and fill the diffusion well with $20 \mu \mathrm{l}$ extract, the concentrations are as follows: $0 ; 0.5 ; 1,0$; $2.0 ; 4.0 \%$. The inhibition categories are determined according to the Davis Stout category (1971). 
Table 1. Determination of extract inhibitory power according to Davis Stout category:

\begin{tabular}{cc}
\hline Inhibition zone & $\begin{array}{c}\text { Inhibition } \\
\text { power }\end{array}$ \\
\hline$\leq 5 \mathrm{~mm}$ & Weak \\
$6-10 \mathrm{~mm}$ & Moderate \\
$11-20 \mathrm{~mm}$ & Strong \\
$>20 \mathrm{~mm}$ & Very Strong \\
\hline
\end{tabular}

\section{Fungi's Colonies Inhibition Test}

Colony inhibition test refers to Hutasoit et al., 2013. $20 \mathrm{ml}$ PDA media which is still liquid is poured into a petri dish that contains an extract with a concentration of $0 ; 0.5 ; 1,0 ; 2.0 ; 4.0 \%$. The petri dish is shaken until the media and extract are evenly mixed and freezing. After the media is frozen, make a diffusion well $\varnothing 5 \mathrm{~mm}$ and then the well is filled with A. niger colonies that have been bred before. Measurement of the diameter of the colony is conducted when the fungi on the control have grown evenly on the petri dish.

\section{Determination of the Total Phenolic Contents}

The total phenolics of the extract were determined using Folin-Ciocalteu reagent. Sample and standards readings were made using a UV-Vis spectrophotometry at $743 \mathrm{~nm}$. The test sample (10 mg) was mixed with ethanol $96 \%(10 \mathrm{ml}) .1 \mathrm{ml}$ of the sample was mixed with Folin-Ciocalteu's phenol reagent. Shake the solution and leave it for 4-8 minutes. Then the solution was added with $4 \mathrm{ml} 7 \% \mathrm{Na}_{2} \mathrm{CO}_{3}$ then added with sterile aquadest to the limit marker. Then it was incubated for 2 hours and the absorbance of the solution was measured at a wavelength of $743 \mathrm{~nm}$ with a blank solution of distilled water and a FolinCiocalteau reagent. The obtained results were measured as an equivalent $\mathrm{mg}$ phenol gallic acid/100 mg fresh sample (Herlinda, 2016).

\section{Determinations of Total Flavonoids Contents}

Dissolve $15 \mathrm{mg}$ extract in $10 \mathrm{ml}$ ethanol to obtain a 1500 ppm solution. Then pipette $1 \mathrm{ml}$ solution, add with $1 \mathrm{ml}$ of $2 \% \mathrm{AlCl}_{3}$ solution, and $1 \mathrm{ml}$ of 120 $\mathrm{mM}$ potassium acetate solution. Then the sample was incubated for one hour at room temperature, absorbance was determined by the UV-Vis Spectrophotometry method at a maximum wavelength of $450 \mathrm{~nm}$ (Stankovic, 2011).

\section{Determination of Total Tannins Contents}

Dissolve $0.5 \mathrm{~g}$ sample with $10 \mathrm{ml}$ aquabidest. Then pipette $1 \mathrm{ml}$ solution and put in a $10 \mathrm{ml}$ container that has been filled with $7.5 \mathrm{ml}$ of aquabidest. Then add $0.5 \mathrm{ml}$ Folin Denis's reagent and incubate 
for 3 minutes. Then, add $1 \mathrm{ml}$ of saturated $\mathrm{Na} 2 \mathrm{CO} 3$ solution. After incubating for 15 minutes, read the absorption at the maximum wavelength (Mukhriani et al., 2014).

\section{Experimental Design}

This study uses a completely randomized design (CRD) with three repetitions in each treatment.

\section{RESULTS AND DISCUSSION}

The MIC results showed that the minimum extract inhibiting $A$. niger was $0.8 \%$. The lowest inhibition zone diameter is $1.3 \mathrm{~mm}$ in $0.8 \%$ extract and the highest inhibition zone diameter is $2.8 \mathrm{~mm}$ in $2 \%$

\section{Statistical Analyses}

The obtained data were analyzed quantitatively using analysis of variance (ANOVA) at the $5 \%$ level and continued with the Duncans Multiple Range Test (DMRT) at the 5\% level if there were significant differences.

extract observed on the 3rd day after incubation. Ethanol extract of Gracilaria sp. below $0.8 \%$ concentration does not have inhibition against $A$. niger, but for the $0.8 \%$ concentrations and above have inhibition against $A$. niger growth.

Table 2. Inhibition zone of Gracilaria sp. extract against $A$. Niger

\begin{tabular}{cccccc}
\hline No. & $\begin{array}{c}\text { Extract } \\
\text { concentration } \\
(\%)\end{array}$ & \multicolumn{3}{c}{ Inhibition zone diameter $(\mathrm{mm})$} & Average \\
\cline { 3 - 5 } & 0.0 & I & II & III & $(\mathrm{mm})$ \\
\hline 1. & 0.1 & 0.00 & 0.00 & 0.00 & $0.00^{\mathrm{a}}$ \\
2. & 0.2 & 0.00 & 0.00 & 0.00 & $0.00^{\mathrm{a}}$ \\
3. & 0.3 & 0.00 & 0.00 & 0.00 & $0.00^{\mathrm{a}}$ \\
4. & 0.4 & 0.00 & 0.00 & 0.00 & $0.00^{\mathrm{a}}$ \\
5. & 0.5 & 0.00 & 0.00 & 0.00 & $0.00^{\mathrm{a}}$ \\
6. & 0.6 & 0.00 & 0.00 & 0.00 & $0.00^{\mathrm{a}}$ \\
7. & 0.7 & 0.00 & 0.00 & 0.00 & $0.00^{\mathrm{a}}$ \\
8. & $0.8 *$ & 2.00 & 1.50 & 0.50 & $0.00^{\mathrm{a}}$ \\
9. & 0.9 & 0.50 & 3.00 & 1.50 & $1.33^{\mathrm{b}}$ \\
10. & 1.0 & 2.50 & 2.00 & 1.00 & $1.66^{\mathrm{c}}$ \\
11. & 2.0 & 4.50 & 1.50 & 2.50 & $2.83^{\mathrm{d}}$ \\
12. & & & & & \\
\hline
\end{tabular}

*MIC value of Gracilaria sp. against $A$. niger

Note: Numbers followed by the same letters in the same column are not significantly different based on the DMRT test at the $5 \%$ level. 
The results of the antifungal activity test using the diffusion well method showed that the crude extract of Gracilaria sp. able to inhibit the growth of $A$. niger fungi on PDA insignificantly and its inhibition is weak. On the first, second, and third days of crude extracts of Gracilaria sp. can still inhibit the growth of $A$. niger, but on the fourth day, Gracilaria sp. has no toxic properties against $A$. niger at all.

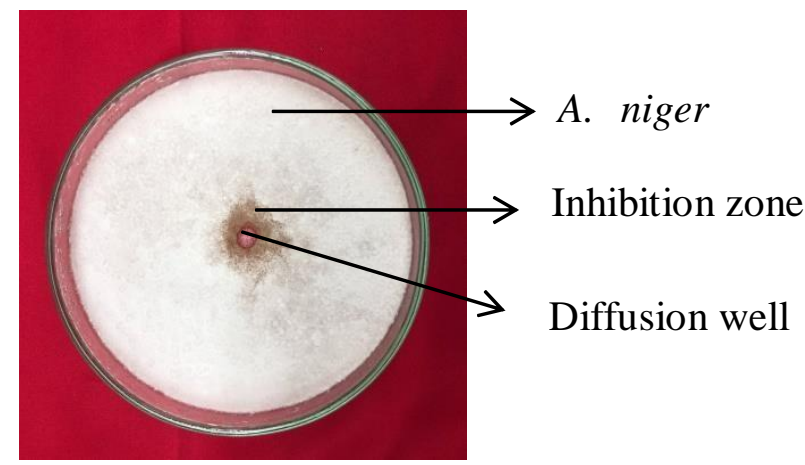

Fig. 1. Inhibition zone of Gracilaria sp. against A. niger at the concetration of $4 \%$

The study showed that the crude extract of Gracilaria sp. except for control treatment and treatment with concentration $0.5 \%$ have weak inhibitory zones $(<5 \mathrm{~mm})$ based on Davis and Stout category with the inhibition power of $0.4 \%$. The results of this study indicate that the crude extract of Gracilaria sp. is not yet fungicidal because it still provides the opportunity for the fungi cells to germinate.

Fungi's colony inhibition test of Gracilaria sp. crude extract against $A$. niger colonies showed that the higher the concentration of the extract given, the smaller the growth of fungal colonies or the greater inhibition of fungal colony growth. The most active extract inhibited was the extract with a concentration of $4 \%$ with inhibition of fungi colonies reaching $69 \%$.
Then the inhibition decreases along with the decreasing concentration of the extract, this shows that the extract which diffuses into the fungi cells also increases and causes the growth of the fungi to be disrupted.

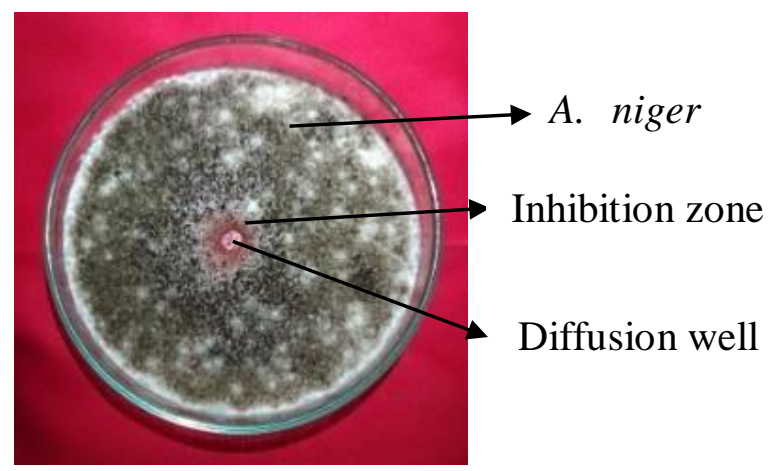

Fig. 2. Inhibition zone of Gracilaria sp. against $A$. niger at the concetration of $4 \%$ after three days 
Table 3. Inhibition zone of Gracilaria sp. against A. niger third day after inhibition

\begin{tabular}{ccccccc}
\hline \multirow{2}{*}{ No. } & $\begin{array}{c}\text { Extract } \\
\text { concentration (\%) }\end{array}$ & \multicolumn{2}{c}{ Inhibition zone (mm) } & Avr (mm) & $\begin{array}{c}\text { Inhibition } \\
\text { power (\%) }\end{array}$ \\
\cline { 3 - 5 } & & I & II & III & & 0 \\
\hline 1. & 0 & 0 & 0 & 0 & 0 & 0 \\
2. & 0.5 & 0 & 0 & 0 & 0 & 0 \\
3. & 1 & 0 & 0 & 0 & 0 & 0 \\
4. & 2 & 0 & 0 & 0 & 0 & 0.4 \\
5. & 4 & 0 & 15 & 0 & 5 & \\
\hline
\end{tabular}

Table 4. Inhibition zone of Gracilaria sp. against A. niger Colonies

\begin{tabular}{ccccccc}
\hline & & \multicolumn{4}{c}{ Colonies diameter (mm) } & \\
\cline { 3 - 6 } No. & $\begin{array}{c}\text { Extract } \\
\text { concentration } \\
(\%)\end{array}$ & I & II & III & Avr (mm) & $\begin{array}{c}\text { Inhibition } \\
\text { power (\%) }\end{array}$ \\
\hline 1. & 0 & 82.50 & 67.00 & 63.00 & $70.83^{\mathrm{e}}$ & 0 \\
2. & 0.5 & 50.00 & 52.00 & 38.00 & $46.66^{\mathrm{cd}}$ & 34 \\
3. & 1 & 44.00 & 46.00 & 45.50 & $45.16^{\mathrm{bc}}$ & 36 \\
4. & 2 & 34.00 & 35.50 & 35.50 & $35.00^{\mathrm{ab}}$ & 50 \\
5. & 4 & 20.00 & 23.00 & 21.16 & $21.38^{\mathrm{a}}$ & 69 \\
\hline
\end{tabular}

Note: Numbers followed by the same letters in the same column are not significantly different based on the DMRT test at the $5 \%$ level.

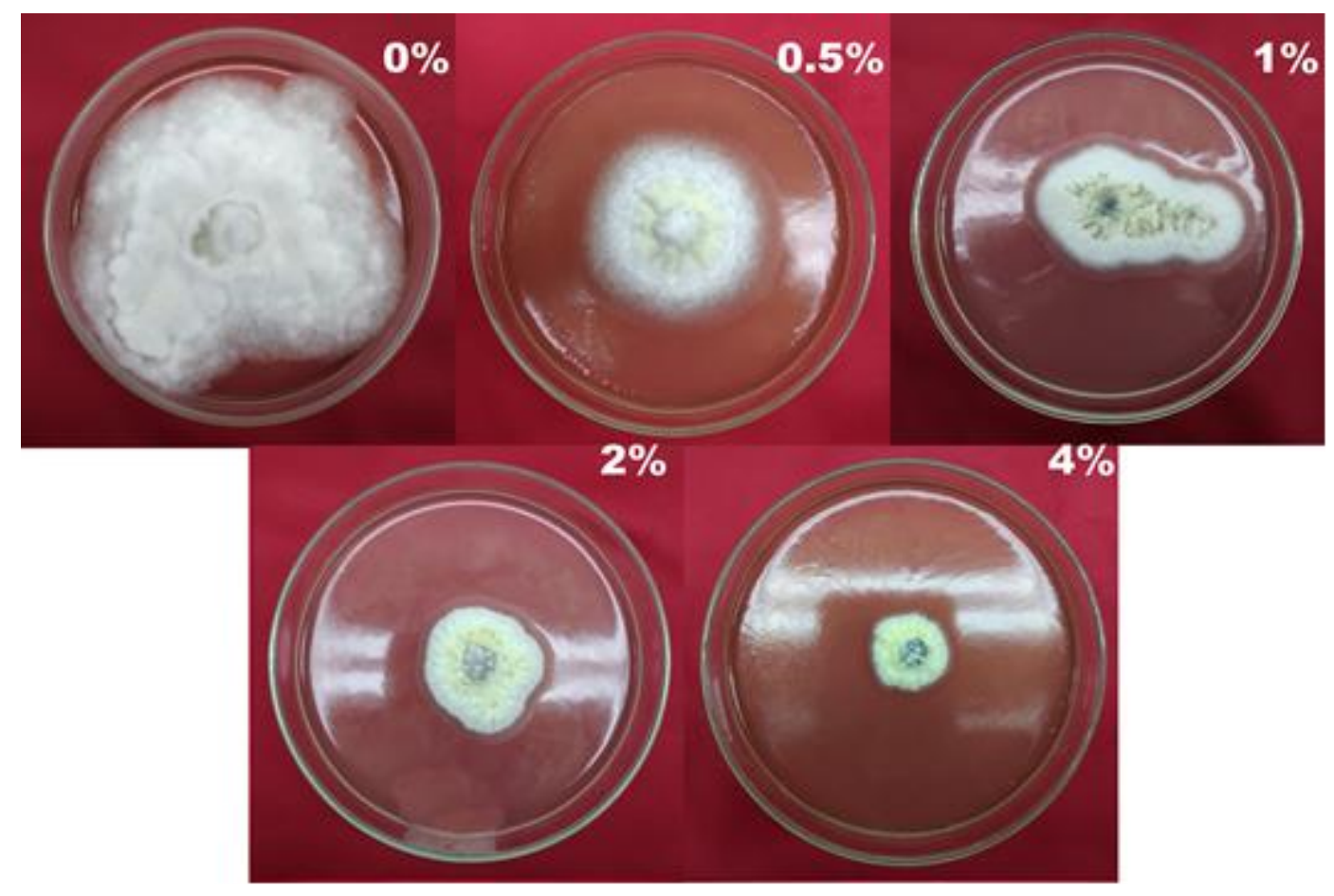

Fig. 3. Inhibition power of Gracilaria sp. against $A$. niger colonies 
The phenol content obtained was expressed as an equivalent $\mathrm{mg}$ of gallic $\mathrm{acid} / 100 \mathrm{mg}$ of a fresh sample. The value of total phenolic content is expressed in Gallic
Equivalents (GAE) per $100 \mathrm{~g}$ dry weight of Gracilaria sp. ethanol extract. The results showed the total phenol ethanol extract of Gracilaria sp. was $366.33 \mathrm{mg} / 100 \mathrm{~g} / \mathrm{GAE}$.

Table 5. Phytochemical analysis of Gracilaria sp.

\begin{tabular}{ccccc}
\hline No. & Sample & $\begin{array}{c}\text { Phenolic total } \\
(\mathbf{m g} / \mathbf{1 0 0 g} / \mathbf{G A E})\end{array}$ & $\begin{array}{c}\text { Flavonoid } \\
(\mathbf{m g} / \mathbf{1 0 0 m g})\end{array}$ & $\begin{array}{c}\text { Tannins } \\
(\mathbf{m g} / \mathbf{1 0 0} \mathbf{g} \text { TAE })\end{array}$ \\
\hline 1. & Gracilaria sp. & 366.33 & 2041.47 & 3041.60 \\
\hline
\end{tabular}

Quantitative analysis method of total flavonoid compounds using UV-Vis spectrophotometry as flavonoids have a conjugated aromatic system that shows a strong absorption band in the ultraviolet spectrum and and visible light spectrum. Based on the results of this study, the levels of flavonoids obtained was $2041.47 \mathrm{mg} / 100$ g.study, the levels of flavonoids obtained was $2041.47 \mathrm{mg} / 100 \mathrm{~g}$.

The determination of tannin content is measured using a tannin standard curve. The tannin standard used was tannic acid. Tannic acid was chosen as it is a hydrolyzed tannins class so that it can be used as a comparison in measuring total tannin levels (Supriyanto, 2011). From this study, it was found that every $100 \mathrm{~g}$ of extract containing tannin was $3041.60 \mathrm{mg} / 100 \mathrm{~g}$ TAE.

\section{CONCLUSION}

This study showed that the ethanol extract of Gracilaria sp. exhibited weak antifungal activity against $A$. niger with the MIC value of 0.8 and inhibitory zones $(<5 \mathrm{~mm})$, and the results showed that the ethanol extract of Gracilaria sp. contained $366.33 \mathrm{mg} / 100 \mathrm{~g} / \mathrm{GAE}$ phenol, $2041.47 \mathrm{mg}$ flavonoids, and $3041.60 \mathrm{mg} / 100 \mathrm{~g} / \mathrm{TAE}$ tannins. Tannins were suspected to be the most dominant fungi static compound with the largest amount.

\section{ACKNOWLAGEMENTS}

This study was supported by Udayana University Research Grant No. 8382/UN14.4.A/LT/2019.

\section{REFERENCES}

Al-Abdallah, A.H.A. 2009. Production of aflatoxins by Aspergillus flavus and Aspergillus niger strains isolated from seeds of pulses. J. Food Agric. Environ. 7(1): 33-39.

Davis, W. W. dan T. R. Stout. 1971. Disc Plate Method of Microbiological Antibiotic Assay. Apllied Microbiology. 22(4): 20-25.

Dewi, N. L. P. S. S., D. N. Suprapta., I. K. Suada. 2019. Uji Efektivitas Ekstrak 
Daun Cengkeh (Syzygium aromaticum L.) terhadap Phytopthora palmivora Penyebab Penyakit Busuk Buah Kakao (Theobroma cacao L.). Jurnal Agroekoteknologi Tropika. 8(4): 80-86.

Gautam, A. K., S. Sharma., S. Avasthi., R. Bhadauria. 2011. Diversity, Pathogenicity and Toxicology of A. Niger: An Important Spoilage Fungi. Reasearch Journal of Microbiology. 6(3): 270-280.

Harborne, J. 1984. Phytochemical Methods A Guide to Modern Techniques of Plant Analysis, Second Edition. New York: Champman and Hall.

Harman, G.E., C.R. Howell, A. Viterbo, I. Chet., M. Lorito. 2004. Trichoderma species opportunisitc avirulent plants symbionts. Nat. Rev. Microbiol. 2(1): 43-56.

Hasibuan, Elliwati. 2015. Pengenalan Spektrofotometri pada Mahasiswa yang Melakukan Penelitian di Laboratorium Terpadu Fakultas Kedokteran USU. Karya Tulis Ilmiah. Pranata Laboratorium Perguruan Tinggi. Fakultas Kedokteran. Universitas Sumatera Utara.

Herlinda, A., A. Malik., A. Najib. 2016. Penetapan Kadar Fenolik Total dari Ekstrak Etanol Bunga Rosella (Hibiscus sabdariffa L.) Berwarna Ungu Menggunakan Spektrofotometri UV-Vis. Jurnal Fitofarmaka Indonesia, 3(1): 210-249.

Lubis, S. S. 2015. Penapisan Bakteri Laut Penghasil Antimikroba dari Pesisir Serdang Begadai Sumatera Utara. Elkawnie: Journal of Islamic Science and Technology. 1(1): 60-78.

Mukhriani. 2014. Ekstraksi. Pemisahan Senyawa, dan Identifikasi Senyawa Aktif. Jurnal Kesehatan. 7(2): 45-63.

Raven, P. H., R. F. Evert, S. E. Eichom. 1992. Biology of Plants, 5th ed. New York: Worth Publishers.

Stankovic, M. S. 2011. Total phenolic content, flavonoid concentration and antioxidant activity of Marrubium peregrium L. Extracts. Kragujevac J Sci, 33 (1): 63-72.

Suada, I. K. 2012. Keberagaman Aktivitas Antifungi Biota Laut Terhadap Fusarium oxysporum f.sp. vanillae Penyebab Busuk Batang Vanili. Jurnal Bumi Lestari, 12(1): 66-70. 